EMBODIED LEARNING: RESPONDING TO AIDS IN LESOTHO'S EDUCATION SECTOR

Dr Nicola Ansell

Centre for Human Geography

Brunel University

Kingston Lane

Uxbridge

UB8 3PH

Phone: 01895266085

Email: nicola.ansell@brunel.ac.uk 


\title{
EMBODIED LEARNING: RESPONDING TO AIDS IN LESOTHO'S EDUCATION SECTOR
}

\begin{abstract}
In contrast to pre-colonial practices, education in Lesotho's formal school system has historically assumed a Cartesian separation of mind and body, the disciplining of students' bodies serving principally to facilitate cognitive learning. Lesotho has among the highest HIV-prevalence rates worldwide, and AIDS has both direct and indirect impacts on the bodies of many children. Thus students' bodies can no longer be taken for granted but present a challenge for education. Schools are increasingly seen as a key point of intervention to reduce young people's risk of contracting the disease and also to assist them to cope with its consequences: there is growing recognition that such goals require more than cognitive learning. The approaches adopted, however, range from those that posit a linear and causal relationship between knowledge, attitudes and practices (so-called 'KAP' approaches, in which the role of schools is principally to inculcate the pre-requisite knowledge) to 'life skills programmes' that advocate a more embodied learning practice in schools. Based on interviews with policy-makers and practitioners and a variety of documentary sources, this paper examines a series of school-based AIDS interventions, arguing that they represent a less radical departure from 'education for the mind' than might appear to be the case. The paper concludes that most interventions serve to cast on children responsibility for averting a social risk, and to 'normalise' aberrant children's bodies to ensure they conform to what the cognitively-oriented education system expects.
\end{abstract}

\section{INTRODUCTION}

This paper concerns the relationship between children's bodies and a society shaken by a disease with which nearly a quarter of adults are now infected. Children's bodies are seen as both products of the disease, weakened and distressed, indirectly, by its consequences; and also points of vulnerability to it. Society (represented by international organisations, national governments and the local membership of school governing bodies) and children's bodies are most forcefully juxtaposed in the space of the school. The paper argues that, whereas schools have always mediated between societies and children's bodies, conventional Western schooling, as practised in the small southern African nation of Lesotho, has subjugated bodies to what has been seen as a higher purpose: the education of the mind. Today, however, in Lesotho, children's bodies have become a key concern for educationalists, acting on behalf of a society (national and international) seeking to respond to AIDS. 
The paper begins by setting out a conceptual basis for exploring how Lesotho's education sector is taking into account children's bodies. It then outlines the ways in which Lesotho's schools have addressed children's embodiment in the past, and the ways in which AIDS is impacting on children's bodies today. The paper draws on a research project that explored education sector policy responses to AIDS. This involved semi-structured interviews with $\mathbf{4 4}$ decision-makers from government, donor agencies, NGOs and other organisations in Lesotho,' and analysis of education policy documents, agency reports and recommendations, curricula and curriculum materials, both from Lesotho and from international agencies and research teams. Various education sector responses are analysed, and a distinction is drawn between those that aim to address the perceived vulnerability of children's bodies (prevention strategies) and those focused on the bodies of children already directly or indirectly affected (mitigation strategies). The paper concludes that these sets of strategies, which operate in part as forms of surveillance, both cast on children the responsibility to minimise risk to society, and seek to normalise children's bodies such that they are once again amenable to education of the mind.

\section{SCHOOLING, BODIES AND SOCIETY}

Because bodies are "both real and figurative, both material and discursive, both sensual and textual' (Moss and Dyck, 1999, p. 67), they are amenable to alternative theoretical treatment. The approach adopted in this paper builds on contemporary scholarship in this field. Until recently, it was common for social scientists to view the body as 'the raw material on which culturally constructed signifiers like gender are inscribed' (Gagen 2004, p. $42 \mathrm{I})$ and therefore of little consequence or inherent interest. Butler (1990) rejecting this essentialist view, instead saw the body as brought into being through its surface markers, rendering identity fundamentally fluid and unstable. For Gagen (2004), this interpretation remains problematic as it assumes that the way bodies relate to identity is always performative. Thrift (1997), too, is critical of the marginalisation of the body as flesh, and a lived entity, within theories of embodiment that focus on the visible, textual, symbolic and interpretive aspects of bodily identity. He and others advocate the value of non-

\footnotetext{
' Education sector policies are products of complex multiscalar interrelations between organisations, personnel and ideas, and represent the diverse actions of a 'society' that is both national and international. Interviews were held with personnel from organisations including UNICEF, UNAIDS, WHO, UNFPA, the EU, USAID, representatives of the Ministry of Education, Ministry of Health, church education offices, education parastatals, local and international NGOs, teachers' unions and youth organisations. On this occasion only minimal research was undertaken within schools or among young people: four interviews were conducted with teachers and head teachers and four focus groups with high school students, but an understanding of children's embodied experiences of, or responses to, policies will require further research.
} 
representational theory, through which bodies are 'understood in their physicality, in the gestures, movements and performances themselves' (Gagen 2004, p. 420).

However, there is a danger in 'celebrating the experiential presence of movement and physicality' (Gagen 2004, p. 423). Physicality and flesh are not unmediated aspects of existence, but have been used for social and political purposes, as Gagen (2004) has demonstrated through her research on the use of playgrounds in early twentieth century America. Programmes of play and recreation that 'reimagined the relationship between identity, consciousness and physicality' (Gagen 2004, p. 424) were informed by psychological theories of child development. Children's physicality was believed to produce particular aspects of character that were deemed to serve a nationalist agenda.

This paper ascribes significance to the materiality of bodies, as bearers of physical needs and the locus of all experience, of sensation, of emotion. Such bodies are also fluid and constantly changing, especially in childhood. But the paper recognises that bodies are also socially and politically constructed. They are 'inflected by material practices, representations, social relations and structures of political-economic power in wider locations such as the home, workplace, community, state and so on' (Valentine, 200I, p. 38). The needs of bodies are not just physically determined, but are ascribed by society. There is a dialectical relationship between the external, the appearance of bodies, as 'surfaces on which values, morality and social laws are inscribed' (Longhurst, 1997, p. 489), and the internal, the sensuous and emotional experience of embodiment. There is also a dialectical relationship between bodies and society (Prout, 2005). Society works on bodies while, in turn, bodies work on society.

Social change is often manifested in bodily change. The arrival of a new disease, for instance, first brings change physically experienced in individual bodies. Such change is accompanied by, and interacts with, changing interpretations of bodies, as bearers of, or vulnerable to, the disease. Bodies and bodily differences are commonly a focus for moral panics (Moss and Dyck, 1999). Responses to such perceived threats seldom focus only on individual diseased bodies, but on the bodies of all who are deemed affected or at risk.

One of the key sites in which society (both adult and child) works on children's bodies is the school. Schools shape children's (experiences of their) bodies. Schools inscribe meanings on children's bodies, and the ways in which children make sense of their bodies, feelings and emotions in part reflects how knowledge of the body is produced and transmitted through 
the practices of the school. Children's bodies also shape their (experiences of) school. Sensations, emotions, and discursive constructions of embodiment impact on how they enjoy, make sense of, and operate within school.

Schools engage and shape children's bodies through overt practices, including the curriculum. In some curricular subjects, such as biology, craft, and physical education, children engage in education about, of, or for bodies. Education may explicitly take place through bodies, through pedagogy that engages the senses, as described in Gagen's (2004) account of American programmes of play and recreation, and Evans' (2006) research on physical education. There are also less explicit means through which schools act on children's bodies, including through surveillance and disciplining. Ultimately all education is experienced through the body, but children are not simply passively shaped, but rather, as active social agents, engage their bodies in resistance, compliance and creative responses. These processes will be explored further in the next section.

\section{DENYING CHILDREN'S EMBODIMENT IN SCHOOL CURRICULA AND PRACTICES}

Historically, Western-style education has seldom given overt attention to children's bodies. This can be explained by reference to the Cartesian mind-body dualism of Enlightenment thought. Within this 'opposition between reason, on the one hand, and the body, affectivity, and desire on the other' (Young, 1987, p. 63), the mind was elevated to a higher status than the body. Schooling was concerned principally with the 'mastery of reason' (Walkerdine 1988), and education through, for and about bodies was sidelined (Paechter, 2004).

Embodiment has also been neglected in education research (Gordon and Lahelma, 1996), and it is only relatively recently that scholars, in geography and more widely, have begun to recognise the significance of children's bodies as a largely unspoken presence in schools.

James et al (1998, p. 42) assert that curricula are 'spatial theories of cognitive and bodily development and as such they contain worldviews'. It is thus significant that attention to the body in school curricula is principally confined to marginal subjects. Some subjects involve learning with/ through the body. Physical education and technology are geared towards improving the body's fitness and dexterity, but such subjects are generally associated with manual labour and afforded a lesser status (Paechter and Head, 1996). Children also learn about bodies. Home economics and personal, social and health education are aimed at increasing awareness of how to maintain bodily health. Nonetheless, even in Western schools where young people's bodies are currently positioned as problematic (Evans, 2006), 
and there is a growing focus on producing healthy bodies through schooling (Hemming, 1997), these subject areas have a marginal status in the curriculum. The only 'high status' subject to focus on bodies is biology, and in this the body is viewed more as a machine or a set of textbook diagrams than a visceral presence in the classroom.

School is, however, experienced viscerally and learning is never disembodied. Students come to understand order through the creation of boundaries and regulations, and through the consequences of transgression (Connor et al., 2004). Through schooling, societies imprint themselves on the bodies of students (Beckett, 2004). '[V]alues and expectations generated and upheld within dominant cultures are transcribed into regulations and inscribed onto student bodies' (Connor et al., 2004, p. 507).

As Paechter (2006, p. 127) highlights, 'children's bodies, and children's sexualities, are both ubiquitous and denied within the school system'. The fact that school children's bodies differ, and that most children's bodies change substantially during the course of their schooling, is not something that schools openly acknowledge or take account of, beyond mundane changes in the size of furniture, and the progressive introduction of (often limited) sex education. Yet much of the organisation of schools is arguably about controlling children's sexuality (Foucault 1978 in Paechter, 2004).

It has been widely argued that '[o]ne of the 'hidden agendas' of the school is to regulate, normalize and discipline children's bodies' (Lupton and Tulloch, 1998, p. 22). Students experience an extreme lack of embodied autonomy in school (Gordon and Lahelma, 1996). They have no privacy, are told what to wear, where to sit, where, when and how to move. In earlier times in Europe, particular bodily postures were specified and required for the practice of writing (Foucault 1977). For centuries, people, time and space in schools have been arranged according to rationalised regimes. The school has thus served as an apparatus of regulation and classification (Walkerdine 1984). The division of groups of young people into age-ordered classes, the use of ranks, classroom arrangements and arrangements of children within them, and regimented timetables have operated as forms of regulation through which power operates (Foucault 1977). The rationale, control and frame of reference for these disciplinary practices is fixed elsewhere and enacted through school. They are enforced in schools in part through surveillance: through the use of monitors in nineteenth century primary schools to help teachers supervise (Foucault 1977), or today in Western schools through growing use of closed-circuit television. Surveillance of these forms imposes on children a 'state of conscious and permanent visibility that assures the 
automatic functioning of power' (Foucault 1977, p. 20I). In combination, forms of regulation and surveillance 'construct child bodies of 'docility-utility': bodies of compliance but also of productivity' (Hemming, 1997, p. 357).

Although regulation and surveillance persist in schools, there has been a shift from overt to covert regulation which mirrors that which has taken place in other areas of Western society (Walkerdine 1988). This move to a lighter, more rapid, more effective exercise of power (Foucault 1977) is manifest in the discourses through which "neoliberal governments work to shape subjects into self-regulating and responsible citizens in order to achieve power over populations' (Hemming, 1997, p. 354). Through physical education lessons, for instance, pupils are controlled through the critical gaze of the teacher, evaluating their fitness levels; the critical gaze of peers (fear of ridicule); but also self-criticism (fear of inadequacy) (Evans, 2006). Even practices of child-centred pedagogy, stemming from a progressive political agenda, in which young children are encouraged to develop as individuals at their own pace, in effect operates through classification and regulation to produce self-regulating subjects (Walkerdine 1988).

Within child-centred pedagogy, which has been highly influential within Western primary education, child development is seen as a science, not of classification but of individual liberation. Yet the use of Piaget's work 'ensures that the child is produced as an object of the scientific and pedagogical gaze by the very mechanisms which were intended to produce its liberation' (Walkerdine 1984, p. 190). Children may be allowed the freedom to discover, but this process is strictly regulated and monitored: 'Pedagogic practices ... are totally saturated with the notion of a normalized sequence of child development' (Walkerdine 1984, p. 155). Although contemporary education may emphasise the production of individuals, this is to be achieved through the 'power of the Norm' (Foucault 1977, p.184). Thus 'normative expectations on children's mind-body regulation are reproduced in classroom spaces, and these can be viewed as part of a hidden agenda to create selfregulating subjects' (Holt 2004, p. 227).

The normalising operation of education, informed as it is by a concern with rationality and science, also serves to marginalise those who are more aware of their embodiment (Kirby 1996). Bodies 'marked by differences deriving from their sex, skin colour, old age, sexuality, physical incapabilities or other variations from the posited 'norm', do not qualify for participation in the liberal democratic model. The materiality of our bodies is seen to exclude us from participating in an ideal of reason' (Duncan 1996, p. 2). Thus the principal 
purpose of practices of control, surveillance and discipline of children's bodies is, in many cases, to make them amenable to education of the mind.

'[T] he main way in which bodies feature in schooling is as things to be policed, to be subdued and got out of the way ... so that we can get on with the main purpose of schooling, the education of the mind ... [W] kept healthy in order to do its job of housing the mind adequately, the main focus in educating the individual will, in this dualistic schema, be on mental capacities and dispositions' (Paechter, 2006, p. 123).

Nonetheless, Hemming (2007, p. 353 ) notes 'children's ability to modify and reconstitute discursive corporeal regimes through their own agency' within primary schools. It is important to recognise that control is never total; nor are schools monolithic (Holt, 2004).

While bodies remain an unspoken presence in most Western-style schooling, some initiatives have understood education as wider than the transmission of knowledge or development of cognitive capacities. A number of critical approaches to education have been developed and implemented. Environmental education, for instance, emphasises affective aspects of students' relationships with the environment (Gurevitz, 2000), insisting that education needs to be about, in and for the environment (Chawla, 2002). A contrasting initiative known as 'Education with Production' was popular in a number of African countries in the years following independence from colonial rule. In reaction to colonial education, the emphasis was on integrating physical and mental aspects of learning, with the intention of upholding the value of physical labour, while not denying children the opportunity to develop intellectually (Nhundu, 1997). Neither of these approaches has had significant success in overturning dominant modes of education that prioritise the mind.

In sum, then, schools have remained outwardly concerned mainly with children's minds, but through a range of areas of curricular and disciplinary practices they have engaged children's bodies materially and discursively in diverse ways. The manner in which such engagements respond to wider social changes will be illustrated in relation to the Lesotho context in the following sections.

\section{EDUCATION IN LESOTHO - WORKING ON CHILDREN'S BODIES?}

The research recounted here was undertaken in Lesotho, a small, mountainous African country of around two million people, entirely surrounded by South Africa. Pre-colonial 
education in Lesotho was very different in focus from Western education. Soon after puberty, young people underwent initiation or 'lebollo', a practice that persists today as an alternative to Western education for some adolescent boys, and to a lesser extent girls. ${ }^{2}$ Intense secrecy surrounds the proceedings, but lebollo is known to be 'a one-class-at-a-time, unisex, formal, group instruction period - lasting from two to eight months' (Montsi, 1978, p. 92), where 'girls and boys separately learned cultural values and philosophy, personal and family responsibilities, and duties to one's clan and people' (Ministry of Education, 1982, p. I). Initiation certainly involves learning about, for and through the body. For both girls and boys, there is an emphasis on manual skills and physical endurance (conditions, particularly for boys whose initiation takes place in remote mountain areas are harsh, and endurance tests may include spending a night standing up). Sex education is also provided (Mturi and Moerane, 200I). Adornment and decoration of the body feature, as does the consumption of special foods. Ultimately, initiation involves the explicit shaping of children's bodies, not merely discursively, but materially. The whole process culminates in circumcision of boys and genital cutting of girls, enacting physical transformation as well as ascribing meaning. ${ }^{3}$

Today, relative to many African countries, Lesotho has high levels of enrolment in Westernstyle schools. A recent Free Primary Education programme has raised the primary gross enrolment rate to $128 \%$ (in excess of $100 \%$ due to children entering school before the age of six, or remaining in school beyond the age of 12 ); and the net enrolment rate to $85 \%$ (Ministry of Education and Training, 2004). More than $70 \%$ of primary school leavers progress to secondary school (Ministry of Education and Training, 2004). Unusually for Africa, at all levels of education, enrolment of girls exceeds that of boys. ${ }^{4}$

Conventional education in contemporary Lesotho has changed little in character from that which arrived with European missionaries and British colonial administrators in the

\footnotetext{
${ }^{2}$ In the early 1990s initiation schools were attended by around 10\% of boys and $2 \%$ of girls (Gill, 1992). Since then attendance among girls has probably fallen but among rural boys is rising. This increasing popularity probably relates to the limited livelihood opportunities for rural boys. Most school leaving boys engage in livestock herding, and 'herdboys' constitute a prominent subcultural group among whom initiation has much greater symbolic value than formal education certificates. Boys who have been through initiation seldom return to formal school, either because schools are reluctant to accept them owing to a perceived clash with the Christian values of church-owned schools, or because they regard themselves as adult men who should no longer accept the authority of women, who constitute the majority of primary school teachers. ${ }^{3}$ Details are unclear. Laydevant (195I) suggests girls' hymen is pierced and the clitoris and labia minora removed. This is disputed by Matsela (1979) given the importance attached to proof of virginity. Others suggest only the last of the three procedures is routine.

${ }^{4}$ There are two reasons for this. Firstly, Basotho men with minimal education could, until recently, find relatively well paid mine work in South Africa. Secondly, owing to the absence of adult men, livestock herding has been undertaken by young boys, limiting their educational opportunities.
} 
nineteenth and twentieth centuries. As such it is viewed as education for the mind. Teaching is very didactic, and curricula are (in practical terms, if not officially) dictated by the demands of end-of-secondary school examinations. Time is spent in acquiring and memorising facts that often bear little relation to life (Ansell, 2002). There is minimal direct attention to bodies in school curricula. Non-academic subjects have a lower status than in contemporary British schools, with at most one practical subject being permitted among those that contribute to certification at the end of secondary school. Those subjects that are taught through or for bodies (vocational subjects and physical education) are given less emphasis as they are not examined, and are also likely to be omitted from school curricula because they require expensive equipment. Learning about bodies takes place within health education ${ }^{5}$ at primary level (which is little emphasised in the curriculum) and in biology at secondary school (although not all schools offer biology to their students).

While Lesotho's schools are minimally concerned with the education of children's bodies, they are highly involved in the regulation and disciplining of bodies. Education is inscribed directly onto children's bodies through strict uniform codes, which in some cases specify different colours for different days of the week: a way of regulating cleanliness as well as appearance. Particular hair styles are required (or at the very least, braided styles are prohibited). As in past decades in the UK, attention is paid to deportment. At morning assembly children stand to attention in files; in class they are expected to sit straight-backed and if they wish to answer a question must raise their hand, and stand to speak. Disorderly bodies - or disorderly minds - are brought back under control through punishment inflicted on the body - a rap on the hands or head with a ruler for minor infringements; whipping for major transgressions among children of either gender (Ansell 1999).

Despite the strict regulation of children's bodies, in some respects Lesotho's schools allow a more relaxed experience of embodiment than those in the UK. Boundaries between students, and between students and teachers, are less rigorously maintained. It is not unusual to see individuals hit one another in jest (including students striking teachers, with no intention to inflict pain). Where textbooks are scarce, a crowd of five or six students may pile on top of each other around a desk in order to see what is being discussed.

\footnotetext{
${ }^{5}$ Lesotho's education sector has been used to address health issues in the past, but these were never prominent, in part because there is no need to confront malaria or tropical diseases that plague other African countries.
} 


\section{AIDS IN LESOTHO: RESHAPING CHILDREN'S BODIES}

This paper is focused particularly on the ways in which schooling in Lesotho is responding to the AIDS pandemic that has inflicted on its population the third highest HIV prevalence in the world. Today $23.2 \%$ of $15-49$ year olds are infected (UNAIDS, 2006). AIDS has many impacts on Lesotho's school children, both direct and indirect. At least $19 \%$ of $0-17$ year olds (UNAIDS/UNICEF/USAID, 2004) have been orphaned. Although few primary school aged children are infected (survival rates among those infected at birth are low), many of those attending secondary school are already HIV-positive. Infection rates reach $14.1 \%$ among 15 24 year old women and 5.9\% among I5-24 year old men (UNAIDS, 2006). Few households are entirely unaffected, and the sickness or death of adult household members often leaves children with some responsibility for undertaking domestic work and income generation and caring for the sick (Robson et al, 2006). Even where children's labour is not required, AIDSaffected households often experience poverty as a result of (sickness-related) unemployment and the high costs of medical care and funerals (Ntozi 1997). Children may go hungry and are in some cases left homeless (Young 2004). Those whose parents die may find themselves heading households of siblings, while others are required to move to a new home, in an environment that is unfamiliar (Ansell and van Blerk 2004). Many move into households that are already impoverished and resentful at having to feed and attend to another child: a situation that breeds discrimination (van Blerk and Ansell, 2006). Furthermore, children affected by AIDS commonly experience stigma (Witter and Were 2004).

As a consequence of AIDS, then, the bodies through which children experience school are changing - both materially and in how they are discursively constructed. Children's bodies may be subjected to illness and malnutrition, physical exhaustion and hunger, inappropriate clothing and emotional distress. It is not only their corporeality that is affected, but also their sensations and emotions and discursive constructions of their needs. If the body and society are reciprocally related, the changing bodies that shape children's experience of education will in turn be reshaped through changes to education. Children's bodies can no longer be taken for granted as simple containers for children's minds. Furthermore, across southern Africa, education sector policies 'describe the impact of HIVIAIDS [on] school-aged children in terms of psychosocial distress, increased malnutrition and reduced learning capacity, loss of school-based health care that includes opportunities for immunisations, homelessness and crime' (SADC, 2002, p. 37). Many of the fears inscribed on children's bodies, particularly around social decay, are embedded in a moral panic around AIDS and the impacts of orphanhood (Bray, 2003). In its responses, Lesotho's education sector faces a challenge to take account of children's bodies in new ways. 


\section{SCHOOLING CHILDREN'S BODIES IN AN ERA OF AIDS}

The focus of this paper is on explicit attempts of society, through education, to work on children's changing bodies in the context of the AIDS pandemic. Schooling to care for children's bodies is deemed necessary to enable them to cope with experiences outside school; to remain physically and emotionally healthy; to perform caring roles; and to reduce vulnerability to HIV infection. Broadly, there are two sets of approaches: 'mitigation' policies intended to address the impacts of AIDS (which address changes assumed to take place in children's own experienced embodiment); and 'prevention' policies, aimed at keeping young people free from HIV infection (which address the perceived vulnerability of children's bodies to infection). Until recently, and still to a large extent, prevention has been given priority over mitigation. It is the vulnerability inscribed on children's bodies that has been the focus of most attention.

There have, however, been broad trends within and between these approaches. The changing emphases of school-based responses to AIDS in Africa have been categorised by the World Health Organisation (WHO, 200I) as a series of five 'generations'. In the mid1980s, first generation responses were fear-driven and emphasised provision of basic facts. This was a time of panic, but although HIV infection is a real and immediate risk to many children, responses were often framed in terms of children's futures due to a denial that children are sexually active in the present (Gwanzura-Ottemoller and Kesby, 2005). The second generation of responses identified by WHO characterised the late-1980s. Young people were deemed to need knowledge to protect themselves, as the discourse moved towards recognising the agency of young people as decision-makers. By the early-1990s (the third generation), policy makers were making use of social and behavioural theories and experience in related fields. AIDS education was no longer equated with sex education, in recognition that knowledge about AIDS and its relationship to sex offers inadequate protection (WHO, 200I). By the fourth generation in the mid-1990s it was understood that young people needed skills in order to confront AIDS. Efforts to address stigma combined with programmes that sought to integrate AIDS education across the curriculum. In the early-2000s, fifth generation school health programmes were promoted with a focus on healthy, safe, secure physical and psychosocial environments. Responses also included skillsbased health education, alongside the development of services to provide care, counselling and support (WHO, 200I). Thus it has only been gradually, over time, that children's bodies have come to be taken more seriously in responses to AIDS, beyond the need for information on how to keep them healthy. 
Drawing on examples from Lesotho, and a range of international studies, the remainder of this paper traces the changing ways in which schools have sought to diminish the vulnerability of children's bodies to HIV infection through prevention strategies, and to address the needs of already affected bodies through mitigation strategies.

\section{PREVENTION STRATEGIES: EDUCATING VULNERABLE BODIES}

While prevention education is clearly about the body, it has generally treated the body as a machine, knowable in a purely abstract, factual way. Subjective experience of embodiment has largely been ignored. Pure transmission of information gradually evolved into what was known as the 'KAP' approach which assumed a linear causal relationship between knowledge, attitudes and practices. In a correctly designed programme, children's increased knowledge about the body would be translated into changes in their attitudes and in turn impact on their behaviour. In many cases, factual knowledge is expected to be coupled with explicit advice to abstain from sex:

'I think that it should be compulsory that a certain proportion of the teacher's time to be dedicated to talking about the body, especially saying to our young ones that wait, that it's best to wait, but also let's be cautious that people are sexually active and be (unclear) otherwise our lives on the line'

(Interview, Lesotho Teachers' Trade Union)

However, across sub-Saharan Africa, AIDS education has not achieved significant behaviour change, despite high levels of knowledge (Bennell et al., 2002). Educating the mind (about the body) does not necessarily translate directly into changes in bodily actions (to protect the body). The concern of society to exercise control over children's bodies, beyond the confines of the classroom, has not been effectively achieved in this way. While society works on children's bodies (Prout 2005), there is not a linear causal relationship between intent and outcome. Governments and others are increasingly absorbed by the challenge of shaping bodies in accordance with their own concerns. They have come to recognise that for children to make use of knowledge about their bodies, attitudinal change (if this was ever achieved through KAP) is not sufficient. Today it is increasingly argued that education is needed that 'also provides the cognitive skills to use that knowledge. Information about HIVIAIDS, and its prevention, can only have real value if those receiving it have the capability to process it ... The mandate of these education systems is therefore to move beyond the transfer of knowledge' (IATT, 2004, p. 109). 


\section{Life skills: beyond abstract body knowledge?}

Throughout much of Africa, there has been a shift, promoted by international agencies (Ansell 2008), towards what have become known as 'life skills programmes'. These are now seen as the best hope for reducing the vulnerability of bodies to HIV, and through this protecting society in general from the pandemic. According to a UNICEF report:

'Young people, especially those between 5 and I 4 years, both in and out of school youth, offer a window of hope in stopping the spread of HIVIAIDS if they have been reached by Life Skills Programmes' (Gachuhi, 1999, p. iv)

The skills deemed necessary go beyond practical and cognitive skills to incorporate interpersonal and psychosocial elements. '[l]n addition to getting the 'facts' about HIV/AIDS, students must develop a healthy awareness of the way in which HIVIAIDS touches their lives. They should have plenty of opportunities to discuss the ethical, social and practical dimensions of the epidemic' (Bennell et al., 2002, p. 44). UNICEF, which is one of the most influential organisations in this field and has worked closely with Lesotho's education ministry to develop life skills education, lists the following areas of skills ${ }^{6}$ that are expected to influence health and social behaviour: ${ }^{7}$

Communication and Interpersonal Skills

- Interpersonal communication skills

- Negotiation/refusal skills

- Empathy

- Cooperation and Teamwork

- Advocacy Skills

Decision-Making and Critical Thinking Skills

- Decision making / problem solving skills

- Critical thinking skills

Coping and Self-Management Skills

- Skills for increasing internal locus of control

- Skills for managing feelings

- Skills for managing stress (UNICEF, 2008)

\footnotetext{
6 The notion of life skills is, nonetheless, interpreted differently by different individuals and organisations, and can incorporate widely diverse skills, as will become apparent.

7 UNICEF's advocacy of life skills is not focused exclusively on AIDS prevention, although the prevention discourse dominates discussion of life skills in the Lesotho context.
} 
One Lesotho organisation involved in developing life skills described their concept thus:

'it's about behaviour change improving people's ways of thinking, training people in emotion management'

(Interview with HIVIAIDS Officer, Lesotho Association of Teachers)

While the emphasis on information provision remains strong in Lesotho, there is a growing focus on 'protective skills-building'.

'The Curriculum and Assessment policy framework development is oriented towards approaches placing primacy on survival skills for learners, not only in their schooling routine but in the local and global community that poses ever daunting challenges in the lives of young people' (Ministry of Education and Training, 2004, p. 9)

Although not explicitly concerned with AIDS, this statement reflects the fact that AIDS (and the life skills curricula intended to address it) is now supposed to suffuse the curriculum. In Lesotho life skills are now integrated into Health and Physical Education (HPE) at primary level, which in turn is integrated into other subjects (particularly science and biology) at secondary level.

\section{Life skills for individual self-empowerment?}

Life skills programmes respond to the perceived vulnerability of children's bodies by challenging educators to not only deliver education about and for the body, but also through children's bodies. However, while they encourage more positive attitudes to bodies and embodiment than is common in conventional Western-style education, they are not unproblematic. For Tania Boler and Peter Aggleton (2005) these programmes place too great an emphasis on the individual. As in the following interview extract, there is an assumption that individuals are able to become autonomous and self-empowered:

'that is my main concern they need to be equipped with life skills. And we make them understand that they have got to stand on their own two feet, they have got to say no to sex, it's not about using condoms and things, it's about valuing their own, loving and valuing their own lives and how do we help them to do that, we 
have got to give them the necessary life skills ... especially for girls to be assertive to know what they want and to go for what they want ...'

(Interview with Inspector, Primary Services, Ministry of Education)

It is, of course, ironic that girls who are assertive and know what they want might actually want sex. This quotation thus reflects an ambiguity between life skills as conceived by international organisations, and local assumptions about how children's bodies should be protected. The life skills discourse, with its emphasis on skills for self-management and 'increasing [the] internal locus of control' (UNICEF, 2008), reflects a Foucaultian form of biopower and draws on the discourses that also underlie health education interventions in the West, wherein children learn to regulate their own bodies. In New Zealand, for instance, 'Policy and professional interventions are increasingly focused on enhancing children's sense of themselves as agentic beings with the emotional, intellectual and cultural resources to make wise choices in a climate replete with health "risks" (Burrows and Wright, 2004, p. 193). While emphasising the individual, this is also about social control. In 'seek[ing] to equip individuals with the skills to enable them to negotiate more 'healthy' lifestyles and discriminate between 'healthy' and 'unhealthy” (Tinning and Glasby, 2002, p. II3), HPE is 'part of a regime of power and knowledge oriented to the regulation and surveillance of bodies for particular ends' (Tinning and Glasby, 2002, p. II5). Persuading children that they are responsible for their own bodies serves to address the vulnerability of society more widely to a threatening disease.

Such an approach also underplays structural (political, economic, cultural) constraints, emphasising risk factors that are within the control of the individual, and thereby casting responsibility fully onto the individual. In Africa, where individual self-identity tends to be very much incorporated within wider relationships (with family, community - the notion of ubuntu), collectivism and solidarity are traditionally seen as more significant than individual autonomy. It may be preferable, for this reason, to develop an approach that emphasises social solidarity and collective empowerment (see Kesby, 2005).

\section{Implementing life skills programmes}

Life skills programmes have not been straightforwardly implemented in Lesotho. There are practical difficulties in integrating the form of education envisaged into a very conventional, didactic style of schooling. This relates partly to the teaching styles that are appropriate to developing the particular skills, and more fundamental contradictions between skills such as critical thinking and the very uncritical way in which knowledge is generally approached in 
Lesotho's schools (Ansell, 2002; Mokuku 2002). Although integrated within Lesotho's school curriculum, not all students are currently exposed to life skills education. ${ }^{8}$ At primary level, HPE is not a core subject - it is not fully tested in exams so has a low priority and is left out of the timetable in some schools (even though $30 \%$ of young people do not progress to secondary school and, for those who do, life skills are integrated into subjects that are not compulsory). As the Health and PE advisor explains:

'The main problem is that subjects like health and PE are not core subjects. They are support subjects, and as a result, they are not being fully tested or examined at the end of the primary leaving, you know, level, which is at the end of 7 years of primary. It's not that much tested, so it's not taught'

(Interview with Health and PE Curriculum Advisor, National Curriculum Development Centre)

Although examination status would increase the importance schools attach to HPE, the HPE curriculum advisors do not want it to be an exam subject because the focus would inevitably be on knowledge about bodies, and would neglect the non-cognitive elements. Its implementation also suffers because teachers are not trained to teach it.

'the problem of examination is you know, we don't teach them to learn. They just want to memorise for examination, and for the health you don't want that, you want them to change their (unclear) and if only they can be made to memorise to pass an examination it is not going to serve our purpose - that's one of the problems we are facing is that we wouldn't really like it to be examined because we know how the examinations, you know, are structured'

(Interview with Health and PE Curriculum Advisor, National Curriculum

Development Centre)

As has been observed elsewhere in Africa (Gwanzura-Ottemoller and Kesby, 2005), teachers often lack confidence to teach sensitive issues or in a different way, but focus on what they are comfortable with - which generally means thinking skills not emotions.

\footnotetext{
${ }^{8}$ There are growing criticisms of the integration approach to life skills education, and many are now advocating full-time life skills teachers and regular timetabled lessons (Bennell et al., 2002).
} 
'we really have a problem with HIVIAIDS because teachers do have some, you know reservations talking about some of the sexual, or you know, things like those, so you really have some problems'

(Interview with Health and PE Curriculum Advisor, National Curriculum

Development Centre)

Where life skills remain largely confined to cognitive skills ('negotiation, conflict resolution, critical thinking, decision-making and communication competencies' (IATT, 2004, p. 109)) there is an assumption that knowledge can be acted upon as a result of rational decisionmaking. This, however, neglects the power of emotion. As in Lesotho's primary curriculum, life skills are often incorporated into Heath and Physical Education (HPE), which 'tends to privilege particular rationalist ways of knowing about health, nutrition and lifestyles' (Tinning and Glasby, 2002, p. 117) and to ignore experienced embodiment.

Life skills education, as delivered through school curricula, still emphasises information delivery, and relatively little attention has been given to pedagogy.

'There is a need to acknowledge that curriculum is far more than what is taught; learning also comes from informal education and observation, practice, hearing, praise and "body language" (IATT, 2006b, p. 7)

The training manuals developed by (Western) NGOs are more focused on alternative ways of teaching than are the curriculum documents. These are often geared towards extracurricular use, which is perhaps an outcome of their origins as prototypes for use in the non-formal settings in which NGOs generally operate, such as school AIDS clubs and peer education. Peace Corps, for instance, seeks to 'Build a bridge from information to behaviour change' (Peace Corps, 2000, p. III-9) through both content and techniques. Content is divided into communication skills, decision-making skills, thinking skills, relationship skills and emotion management skills. Techniques advocated include role play, forum theatre, games, puzzles and group discussions. Broadly, these NGO manuals emphasise the significance of body language, and give advice on using the body in teaching. The body is accorded a high profile, both in terms of providing information about bodies, but also, for instance, exercises involving learners talking about their bodies, and the aspects that they like. Such manuals also engage with emotions, using learners' emotions in putting across the manuals' messages, on the basis of the need for 'activities that engage emotional and visceral registers and tap into pre-cognitive states' (Cameron and Gibson, 2005, p. 328). 
Life skills manuals, then, present ways of learning for the body, through the body. The emphasis on skills can, however, detract from learning about bodies. ${ }^{9}$ The use of activities like the body mapping exercise, which appears in several manuals, in which students draw around one another's bodies and annotate their drawings, provide a way of learning about their bodies that relates more to their own bodies than to a generic or abstract body and as such is more likely to be have application in their own embodied lives. ${ }^{10}$ Such teaching begins to acknowledge that bodies are experienced subjectively, but the extent to which it is implemented in Lesotho's schools depends very much upon the teachers using the manuals.

Evidence on the efficacy of life skills programmes in altering behaviour is unclear; while a number of studies have shown that such programmes increase young people's knowledge in relation to AIDS, evidence on changes in behaviour is less convincing (James et al 2006; Magnani et al 2005; Visser 2005). In this respect, they have proved little more powerful than KAP approaches, and again suggest that through current implementation measures, schools in Lesotho are unable to significantly increase their control over children's bodies, or assist young people to avoid infection.

\section{MITIGATION STRATEGIES: CARING FOR CHILDREN'S BODIES?}

It is now widely accepted that "care and support has lagged behind awareness and prevention activity' (IATT, 2006a, p. 50), and there are growing moves for schools to address the needs of orphans and other AIDS-affected children, including those caring for sick family members. In Lesotho, curriculum developers consider it:

'important for every, you know, primary child, to know the basic knowledge about HIVIAIDS. And especially about the care, care and support, because we are now facing a problem where we really have people out there who are in operations, or who are in, you know, so these children are unfortunately taking care of those people out there, you know, over and above the general knowledge or the basic knowledge about HIVIAIDS'

\footnotetext{
${ }^{9}$ There may be a temptation to focus on skills at the expense of bodies, as teachers are seldom at ease discussing sex and sexuality with students. 'Attempts to deliver HIV and AIDS education in schools are severely restrained by social and cultural norms, and sexual relations and power inequalities. These constraints will often manifest themselves in selective teaching, where messages on HIV and AIDS are either not communicated at all, or restricted to overly scientific discussions without reference to sex or sexual relationships' (IATT, 2006b, p. 27).

${ }^{10}$ This method has also been used in health-related research with children (Mitchell, 2006).
} 
(Interview with Health and PE Curriculum Advisor, National Curriculum Development Centre)

It is recognised that 'the needs of OVC"I go beyond formal schooling, including psycho-social and material needs. HIV and AIDS counselling services should be supported' (IATT, 2006a, p. 47). Ministries acknowledge the need to explore combining educational provision with care and welfare for orphaned children (Ministry of Education and Training, 2002) and those caring for the sick, yet across southern Africa little support is currently available for children affected by AIDS.

Schemes aimed at caring for children's bodies focus both on the physical and the emotional. In terms of physical welfare, initiatives have included school feeding programmes; provision of food packages for holidays; vegetable gardens; delivery of anti-retroviral therapy (with attendant 'treatment education' including 'prevention for positives'); keeping schools open at night; second hand uniform sales and uniform grants. ${ }^{2}$ In relation to children's emotional welfare, the Government of Lesotho aims to train one in three teachers as a lay counsellor. There is a recognised 'need to train teachers in psycho-social care and support techniques such as play therapy' (Ministry of Education and Training, 2004, p. I I).

While these forms of care are undoubtedly responses to concerns about children's embodied experiences of life, and of school, the emphasis remains on education. IATT (2006b, p. 6) suggests that schools should:
'acknowledge what the learner brings such as previously uncommon experiences and backgrounds which may both enhance and/or hinder his/her and others' learning. These could include family or income-generating responsibilities or psychosocial trauma, increased poverty and/or diminished health status'

This exemplifies the continued focus on (cognitive) learning as education's primary objective. In terms of the interrelationship between bodies and school, the fact that bodies affect experiences of school prompts schools to modify or recode bodies to the extent that they once again become amenable to education of the mind. These mitigation strategies, then, might be seen as no more than measures for normalising troublesome bodies.

\footnotetext{
"Orphans and vulnerable children. This term is used both to acknowledge that it is not only orphanhood that renders children vulnerable, and also to avoid stigmatising orphaned children.

12 The first three of these initiatives are widely practised in Lesotho but others depend on individual teachers and schools.
} 
Mitigation strategies are not focused exclusively on the immediate needs of aberrant bodies, though. Like prevention strategies, there is also a concern for children's futures. Once again, life skills programmes, rather differently conceived, are seen as having a role to play in enabling orphans to take care of their bodily needs.

'I think we need to give them life skills so that even when they become orphans when they finally lose parents they are able to go on in life because you look at the family structure, the extended family structure, it's collapsed ... Do we still allow schools to remain what they were or are we going to change our schools so that they facilitate for both the vulnerable and the not vulnerable, because, the orphans, who teaches them, em for example I teach my daughter, wash your clothes, do what, do what. Who does that with the orphans? What do we do to the school, to the education system so that it accommodates both the vulnerable and the nonvulnerable, that the teacher does not only talk about Christopher Columbus, does not only talk about the first world war, but also talks about basic hygiene for the benefit of this one who will not have anybody talking about that at home. Basic agricultural skills for this one who will not have anyone giving such instruction at home. Do we let schools remain what our primary schools remain what they have always been or are we going to do something to make them change so that these orphans and other vulnerable children are covered and equipped with life skills?'

(Interview with Inspector, Primary Services, Ministry of Education)

Programmes delivering such practical skills for body care are widely advocated, leading some to argue that the notion of life skills has become too diffuse (Boler and Aggleton, 2005). However, while there are doubtless substantive differences between skills of body care and, for instance, critical thinking, to overemphasise such a distinction would be to reinforce the mind-body dualism that such programmes may begin to blur.

\section{CONCLUSIONS: OUTCOMES OF INTERVENTION AND PRACTICES OF POWER}

In an era of AIDS, children's bodies cannot be ignored in Lesotho's schools, but pose a challenge for the education system that has become the focus of numerous interventions. In many respects this new attention to children's bodies as more than simply receptacles for the mind is to be welcomed, after a century or more of education that sought to dismiss the embodiedness of its subjects. Increasingly it seems, knowledge is recognised 'as embodied, 
engendered and embedded in the material context of place and space' (Duncan, I996, p. I). This new attention to bodies may not, however, be so radical a departure as it first appears. Prevention strategies, on the one hand, reinforce the inscription of children's bodies as vulnerable points for the penetration of disease in society, but also, in educating children to exercise control over their own bodies and emotions, cast them as individually responsible for addressing a social risk. Mitigation strategies, on the other, seek to address the immediate (mainly indirect) impacts of AIDS on children's bodies, but do so largely out of a concern to 'normalise' those bodies, returning them to a state that is amenable to cognitive learning.

While the aim of this paper has not been to identify how, or explain why, particular policy prescriptions or interventions emerge, it is appropriate very briefly to place these in a wider political context. As Moss and Dyck (1999, p. 10) point out: 'The body is both object and target of power'. Interventions in schools represent an exercise of power (albeit not entirely effective) on the part of society, but as was outlined above, society in Lesotho, represented by the actors and agencies involved in the education sector, is heterogeneous and involves a powerful international component. Donor agencies and international NGOs exercise considerable influence, and undoubtedly bring Western norms to bear in prescribing policies and advocating practices. As with the introduction of Western-style schooling in the late nineteenth century, life skills programmes and other interventions are in many (but not all) respects foreign. Western culture is accused of a 'cult of the body' public discourse 'in which the health status and vulnerability of the body have become central themes of existence in contemporary Western society' (Tinning and Glasby, 2002, p. I I0). Such a cult, combined with a desire to regulate bodies that are young, poor and black, arguably informs the international discourse that is put into practice through policy interventions in African schools. That the latest UNAIDS (2006) Report on the global AIDS epidemic includes as a 'country progress indicator' the 'Percentage of schools with teachers who have been trained in life-skills-based HIV education and who taught it during the last year' (p. 550) indicates the extent of international enforcement through surveillance. Any search for an explanation of the changing place of children's bodies in Lesotho's schools cannot neglect this influence.

\section{REFERENCES}

Ansell N 1999 Southern African secondary schools: places of empowerment for rural girls? PhD Thesis, Keele University 
Ansell, Nicola (2002) Secondary education reform in Lesotho and Zimbabwe and the needs of rural girls: pronouncements, policy and practice, Comparative Education, 38, 91112.

Ansell, N (2002) "Of course we must be equal, but ...': imagining gendered futures in two rural southern African secondary schools' Geoforum 33, 179-194

Ansell, N (2008) Producing interventions for AIDS-affected young people in Lesotho's schools: scalar relations and power differentials (manuscript under review)

Ansell N and van Blerk L 2004 'Children's migration as a household/family strategy: coping with AIDS in Malawi and Lesotho' Journal of Southern African Studies 30(3), 673-690

Beckett, Lori (2004) Editorial: health, the body, and identity work in health and physical education, Sport, Education and Society, 9, I7I-I73.

Bennell, Paul, Hyde, Karin and Swainson, Nicola (2002) The impact of the HIVIAIDS epidemic on the education sector in sub-Saharan Africa: a synthesis of the findings and recommendations of three country studies: Centre for International Education, University of Sussex Institute of Education.

Boler, Tania and Aggleton, Peter (2005) Life skills-based education for HIV prevention: a critical analysis, London: Save the Children and ActionAid International.

Bray, Rachel (2003) Predicting the social consequences of orphanhood in South Africa, African Journal of AIDS Research, 2(I), 39-55.

Burrows, Lisette and Wright, Jan (2004) The good life: New Zealand children's perspectives on health and self, Sport, Education and Society, 9, 193-205.

Butler, Judith (1990) Gender trouble: feminism and the subversion of identity, Routledge: London.

Cameron, Jenny and Gibson, Katherine (2005) Participatory research in a poststructuralist vein, Geoforum, 36, 3I5-33I.

Chawla, Louise (2002) 'Insight, creativity and thoughts on the environment': integrating children and youth into human settlement development, Environment and Urbanization, 14, II-2I.

Connor, David J, Newton, Roberta M, Pennisi, Alice C and Quarshie, Antoinette A (2004) Tales of body/space invasions in school, Qualitative Inquiry, 10, 495-508.

Duncan, Nancy (1996) Introduction: (re)placings, in Duncan, Nancy (ed.) BodySpace, London: Routledge.

Evans, B (2006) 'l'd feel ashamed': girls' bodies and sports participation, Gender, Place and Culture 13, 547-56I.

Foucault, M (1977) Discipline and punish: the birth of the prison, London: Penguin 
Gachuhi, Debbie (1999) The impact of HIVIAIDS on education systems in the eastern and southern Africa region and the response of education systems to HIVIAIDS., New York: UNICEF.

Gagen, E A (2004) Making America flesh: physicality and nationhood in early twentiethcentury physical education reform, Cultural Geographies II, 4I 7-442

Gill, Debby (1992) Lesotho: a gender analysis., Maseru, Lesotho: Sechaba Consultants.

Gordon, Tuula and Lahelma, Elina (1996) 'School is like an ants nest': spatiality and embodiment in schools, Gender and Education, 8, 301-310.

Gurevitz, Rachel (2000) Affective approaches to environmental education: going beyond the imagined worlds of chihldhood?, Ethics, Place and Environment, 3, 253-268.

Gwanzura-Ottemoller, F and Kesby, M (2005) 'Let's talk about sex, baby ...': conversing with Zimbabwean children about HIVIAIDS, Children's Geographies, 3, 20I-2I8.

Hemming, PJ (1997) Renegotiating the primary school: children's emotional geographies of sport, exercise and active play, Children's Geographies, 5, 353-37I.

Holt, L (2004) Children with mind-body differences: performing disability in primary school classrooms, Children's Geographies, 2, 219-236.

IATT (2004) Report on the Education Sector Global HIV/AIDS Readiness Survey, IIEP/UNESCO Paris: UNAIDS Inter-Agency Task Team on Education.

IATT (2006a) Education Sector Global HIV \& AIDS Readiness Survey 2004: policy implications for education and development, UNESCO Paris: UNAIDS Inter-Agency Task Team on Education.

IATT (2006b) Quality Education and HIV\&AIDS, UNESCO Paris: UNAIDS Inter-Agency Task Team on Education.

James, A, Jenks, C and Prout, A (1998) Theorising childhood, Cambridge: Polity

James, S, Reddy, P, Ruiter, RA, McCauley, A, van den Borne, B. (2006) The Impact of an HIV and AIDS Life Skills Program on Secondary School Students in KwaZulu-Natal, South Africa, AIDS Education and Prevention 18, 28I-294.

Kesby, Mike (2005) Retheorizing empowerment-through-participation as a performance in space: Beyond Tyranny to transformation, Signs, 30, 2037-2065

Kirby, K M (1996) Re: mapping subjectivity: cartographic vision and the limits of politics, in Duncan, Nancy (ed.) BodySpace, London: Routledge.

Laydevant, Francois (195I) The rites of initiation in Basutoland, Roma, Lesotho: The Social Centre, St Michael's Mission.

Longhurst, Robyn (1997) (Dis)embodied geographies, Progress in Human Geography, 21, 486501 . 
Lupton, D and Tulloch, J (1998) The adolescent 'unfinished body', reflexivity and HIV/AIDS risk, Body and Society, 4, 19-34

Magnani, R; Maclntyre, K; Karim, AM; Brown, L; Hutchinson, P (2005) The impact of life skills education on adolescent sexual risk behaviors in KwaZulu-Natal, South Africa, Journal of Adolescent Health, 36 (4) 289-304

Matsela, Fusi Zacharias A. (1979) The indigenous education of the Basotho and its implications for educational development in Lesotho: University of Massachusetts.

Ministry of Education and Training (2002) Thematic discussion on HIVIAIDS and education, Meeting of the SADC ministers of human resource development sector: Ministry of Education and Training, Lesotho.

Ministry of Education and Training (2004) National Report on the Development of Education, Kingdom of Lesotho, International Conference on Education, Geneva.

Ministry of Education, Sports and Culture (1982) The Education Sector Survey: Report of the Task Force.

Mitchell, Lisa M (2006) Body and Illness: Considering Visayan Filipino Children's Perspectives within Local and Global Relationships of Inequality, Medical Anthropology, 25(4), 33I373.

Mokuku, Tsepo (2002) 'Sustainable development in a post-colonial context: the potential for emancipatory research' in van Rensburg E J, Hattingh J, Lotz-Sisitka $\mathrm{H}$ and O'Donoghue R (eds) Environmental education, ethics and action in southern Africa HSRC, Pretoria, pp. I35-I45.

Montsi, Mercy Rapelesega (1978) A study of the self-concept of Basotho male and female adolescents in secondary schools.: University of Massachusetts.

Moss, Pamela and Dyck, Isabel (1999) Journeying through M.E.: identity, the body and women with chronic illness, in Teather, Elizabeth Kenworthy (ed.) Embodied geographies: spaces, bodies and rites of passage, London: Routledge.

Mturi, A J and Moerane, W 200I 'Premarital childbearing among adolescents in Lesotho' Journal of Southern African Studies 27(2), 259-275.

Nhundu, Tichatonga J (1997) The effects of policy marginalization on the implementation of a curriculum innovation: a case study of the implementation of education with production in Zimbabwe, Journal of Curriculum Studies, 29, 47-70.

Ntozi J P M 1997 'Effect of AIDS on children: the problem of orphans in Uganda' Health Transition Review 7(supplement), 23-40

Paechter, Carrie (2004) 'Mens sana in corpore sano': Cartesian dualism and the marginalisation of sex education, Discourse: Studies in the Cultural Politics of Education, 25, 309-320. 
Paechter, Carrie (2006) Reconceptualizing the gendered body: learning and constructing masculinities and femininities in school, Gender and Education, 18, I2I-135.

Paechter, Carrie and Head, John (1996) Gender, identity, status and the body: life in a marginal subject, Gender and Education, 8, 21-29.

Peace Corps (2000) Life Skills Manual, Washington DC: Peace Corps Centre for Field Assistance and Applied Research.

Prout, Alan (2005) The future of childhood, Abingdon: RoutledgeFalmer.

Robson E, Ansell N, Huber U, Gould W and van Blerk L 2006 'Young caregivers in the context of the HIV/AIDS pandemic in sub-Saharan Africa' Population, Space and Place I2(2), 93-III

SADC (2002) National and sector HIVIAIDS policies in the member states of the Southern African Development Community: Prepared for the SADC/HSU by the POLICY Project.

Thrift, N (1997) The still point: resistance, expressive embodiment and dance, in S. Pile and M. Keith, eds, Geographies of resistance, London: Routledge, Pp. I24-5I.

Tinning, Richard and Glasby, Trish (2002) Pedagogical work and the 'cult of the body': considering the role of HPE in the context of 'new public health', Sport, Education and Society, 7, 109-119.

UNAIDS (2006) Report on the global AIDS epidemic, Geneva: UNAIDS.

UNAIDS/UNICEF/USAID (2004) Children on the brink: a joint report of new orphan estimates and a framework for action, New York.

UNICEF (2008) 'Which skills are life skills', accessed 27/06/2008, http://www.unicef.org/lifeskills/index_whichskills.html Valentine, Gill (200I) Social geographies: space and society, Harlow: Prentice Hall.

van Blerk L and Ansell N (2006) 'Children's experiences of migration: moving in the wake of AIDS in southern Africa' Environment and Planning D: Society and Space 24, 449-47I

Visser, MJ (2005) Life skills training as HIVIAIDS preventive strategy in secondary schools: evaluation of a large-scale implementation process, SAHARA: Journal of Social Aspects of HIVIAIDS Research Alliance 2, 203-216

Walkerdine, $V($ 1984) Developmental psychology and the child-centred pedagogy: the insertion of Piaget into early education, in Henriques, J, Hollway, W, Urwin, C, Venn, C and Walkerdine, V Changing the subject: psychology, social regulation and subjectivity, London: Methuen pp. 153-202

Walkerdine, V (1988) The mastery of reason: cognitive development and the production of rationality, London: Routledge 
WHO (200I) Education for health prevention: an obligation for all of us, in Education International (ed.) Dossier: Education in the era of HIVIAIDS.

Witter S and Were B (2004) 'Breaking the silence: using memory books as a counselling and succession-planning tool with AIDS-affected households in Uganda' African Journal of AIDS Research 3(2), 139-143

Young, I M (1987)

Young L (2004) 'Journeys to the street: the complex migration geographies of Ugandan street children' Geoforum 35, 47/ -488 